$\xi=-1$

\title{
Bidirectional de to de Converters: An Overview of Various Topologies, Switching Schemes and Control Techniques
}

\author{
Deepak Ravi ${ }^{1}$, Bandi Mallikarjuna Reddy ${ }^{2}$, Shimi S.L. ${ }^{3}$, Paulson Samuel $^{4}$ \\ ${ }^{1,3}$ National Institute of Technical Teachers Training and Research, Chandigarh \\ ${ }^{2,4}$ Motilal Nehru National Institute of Technology Allahabad, Allahabad \\ *Corresponding author E-mail:dpsngh990@ gmail.com
}

\begin{abstract}
Bidirectional dc to dc converter is used as a key device for interfacing the storage devices between source and load in renewable energy system for continuous flow of power because the output of the renewable energy system fluctuates due to change in weather conditions. In electric vehicles also, bidirectional converter is used between energy source and motor for power supply from battery to motor. Thus, bidirectional dc to dc converters are getting more and more attention in academic research and in industrial applications. Bidirectional dc to dc converters work in both buck and boost mode and can manage the flow of power in both the direction between two dc sources and load by using specific switching scheme and phase shifted control strategy and hence generated excess energy can be stored in batteries/super capacitors. Therefore, the basic knowledge and classification of bidirectional dc to dc converters on the basis of galvanic isolation, the comparison between their voltage conversion ratio and output current ripple along with various topologies researched in recent years are presented in this paper. Finally, zero current and zero voltage soft switching schemes and phase shifted controlling techniques are also highlighted.
\end{abstract}

Keywords: DHB-IBDC (Dual half bridge-isolated Bidirectional dc-dc converter); DAFB-IBDC (Dual Active full bridge-isolated bidirectional dc-dc converter); IBDC (Isolated Bidirectional dc-dc converter); NIBDC (Non-isolated Bidirectional dc-dc converter);

\section{Introduction}

Recently the use of renewable energy resources has been increased to save the environment and remaining fossil fuel and the requirement of storing the energy is also increased. In many applications like electric vehicles the need of interfacing of energy storage with load and source is increased for a reliable and efficient system. Bidirectional dc to dc converter is the main device used to interface the Battery and super capacitor as a storage device to increase the system reliability. Moreover, As shown in FIG. 1.(a), in electric vehicle bidirectional dc-dc converters used for capturing the kinetic energy of motor and charging the battery during regenerative breaking by reverse flow of energy [1]-[5][6]. Similarly, the output of the hybrid system in Fig 1(b) the consisting of wind energy, solar energy etc. are environment dependent so fluctuation of output power and sudden change in load demand makes this hybrid system unreliable so, the solution for this issue is use of storage system like battery, super capacitor etc. with the help of bidirectional dc to dc converter for power conditioning and smooth flow of power to the load [7]-[10] . In industrial application also, bidirectional dc-dc converters are used in many applications because devices are switch on and off at high frequency so DAB (Dual active bride)-IBDC (isolated bidirectional $\mathrm{dc}$ to $\mathrm{dc}$ converter) provide both galvanic isolation, storage of surplus energy and efficient flow of power without wasting the energy [11]. For proper understanding of hybrid energy system and electric vehicle, it is necessary to have knowledge the working principle of dc to dc converter. Therefore, this paper discusses the basic concept of bidirectional dc to dc converter, their classification based on galvanic isolation and various topologies such as interleaved converter and DAB converter. Also, the comparison between soft Switching and hard switching schemes is given. Finally, different control strategies such as SPS (single-phase shift), DPS (double phase shift), EPS (extended phase shift) and TPS (triple phase shift) employed in IBDC for bidirectional power flow are highlighted.

\section{Bidirectional de to dc Converter}

A conventional buck-boost converter can management the power flow in one direction only but power can flow in both the direction in bidirectional converter. Bidirectional dc-dc converters are the device for the purpose of step-up or step-down the voltage level with the capability of flow power in either forward directions or in backward direction. Bidirectional dc-dc converters work as regulator of power flow of the DC bus voltage in both the direction. In the power generation by wind mills and solar power systems, output fluctuates because of the changing environment condition. These energy systems are not reliable to feed the power as a standalone system because of the large fluctuations in output and hence these energy system systems are always connected with energy storage devices such as batteries and super capacitors Fig. 1(b). These energy storage devices store the surplus energy during low load demand and provide backup in case of system failure and when the output of energy system changes due to weather conditions. Thus, a bidirectional dc-dc converters are needed to allow power flow in both forward and backward the directions [12]-[18]. A conventional dc-dc converter can be converted into a bidirectional converter using bidirectional switch by using diode 
in anti-parallel with MOSFET or IGBT allowing current flow in both the direction using controlled switching operation.

\section{Types of Bidirectional Converter}

There are two types of Bi-directional dc/dc converter on the basis of galvanic isolation provided between input and output [19].

$$
\text { - } \quad \text { NIBDC }
$$

- $\quad$ IBDC

\subsection{Non-Isolated Bidirectional Dc to Dc Converter (NIBDC)}

NIBDC is a converter which does not use high frequency transformer to provide any electrical isolation between source and load. Hence these converters are not used in high power applications due to safety reasons but in low power application theses converter are more efficient because these are easy to control and light weight due to absence of transformer [20].

\subsubsection{Bidirectional Buck-boost Converter}

This topology is basic circuit of bidirectional dc-dc converter Fig.1 (c). It is the anti-parallel combination of buck-boost converters. During the step-up operation Q1 is conduct according to the duty cycle whereas Q2 will not conduct in this mode. In stepdown mode Q2 will conduct according to the duty cycle and Q1 will not conduct in this mode. A small dead time provided between both the operation so that cross conduction can be avoided [17][21]. Given topology is a non-isolated half-bridge BDC topology and it is designed by the combination of boost converter connected antiparallel with buck converter [22], [23]. This topology is simple and has greater efficiency [24].

\subsubsection{Cascaded Bidirectional Buck-boost Converter}

This topology Fig. 1(d) is obtained by cascading buck converter with boost converter [28]-[31]. With this topology all four quadrant is possible hence this topology works as buck mode and boost mode in both the direction. 4-quardant operation of this topology makes this topology most flaxible but it has some limitations also: more number of switches which leads to more switching losses, complex control algorithm and more turn-on losses because of reverse reconevry of diodes

\subsubsection{Bidirectional CUK Converter}

Bidirectional CUK converter [25] is obtained from unidirectional CUK converter by using MOSFET in place of diode Fig. 1 (e). The output of this converter has low ripple as compared to above described topologies hence this converter can be a better option for interfacing super-capacitor-battery in circuits [26], [27]. The ripple output current can be reduced by coupling of inductor L1and L2. In the forward power flow, Q1 works as controlled switch and Q2 remain off and body diode of switch Q2 works as main diode. Similarly, in backward power flow Q2 works as controlled switch and Q1 remain off and body diode of switch Q1 works as main diode.

\subsubsection{Bidirectional SEPIC-ZETA dc to de Converter}

SEPIC-ZETA dc to dc converter is modification of CUK converter so its output is not opposite polarity like CUK converter Fig. 2(a). In forward power flow mode this converter works as SEPIC converter and in negative power flow mode, this converter works as ZETA. SEPIC-ZETA converter works in both buck and boost mode [28], [29]. In forward power flow, switch Q1 turn on and Q2 remain off and it works as buck converter and in backward power flow mode it works as boost converter with Q2 turn off. Coupling of inductor L1 and L2 can reduce the voltage output ripple and voltages rating stress on switches.

\subsubsection{Switched Capacitor Bidirectional de to dc Converter}

Fig. 2 (b) shows the switched capacitor bidirectional dc-dc converter which is used when ICs (integrated Circuits) are to use in dc-dc converter circuits[30]-[32]. Since no magnetic devices are present in non- isolated dc-dc converter, integrating of ICs are quite simpler. But theses converters suffer from high ripple current in output due to large number of passive component that leads to electromagnetic interference (EMI). These problems can be resolved by control scheme such as current control and voltage control techniques but this will increase the complexity and cost of the circuit.

\subsubsection{Interleaved Non-isolated Bidirectional de to dc Convert-} er

Interleaved converter is the parallel combination of two or more than two converters with relative phase shift $360 \%$. Interleaved converters have some the advantages: current splitting (I/n), cancellation of ripples in output current, higher efficiency of system, high-power density and, higher thermal capacity. Due to the current splits in parallel paths, conduction losses decrease with less number of switches. With the interleaving method in dc-dc converter, the ripple of the input current and the output voltages decreases without increasing the switching losses which leads to higher system efficiency [33].

\subsubsection{2-phase Interleaved Non-Isolated Bidirectional dc-dc} converter

$2-\varnothing$ interleaved converter contains two output stages which is 180 degrees out of phase. Conduction losses $\left(i^{2} r\right)$ are reduced by dividing the current into two paths which are connected parallel. More over overall efficiency increases as compared to 1- $\varnothing$ converter. Due to 2-phase combines at the capacitor which is connected at output, effective ripple frequency becomes doubled which reduces ripple in output voltage. Also, power pulses coming from the input capacitor are stumbled and reduces ripple in current. In Fig. 2(c) basic circuit of 2-phase interleaved dc-dc converters is discussed. Interleaved half bridge converter is the mostly used topology [19][34]-[36]. Theses converter facilitates higher voltage conversion with smaller size of converter. The switching losses also decreases [37]. Hence these converters can be employed to interface ultra-capacitor/battery hybrid energy system for automotive applications like hybrid electric vehicle. Interleaved converter are designed as follows [38]:

- Decide the duty ratio

- Decide the number of phases

- Choose proper Inductor values

- Choose a power semiconductor switch

- Design of filter

These converters have some issue such as: high in cost due to the increased number of component and complex the control strategy.

\subsection{Isolated Bidirectional de to dc Converter}

NIBDC are not capable to provide the safety standards of galvanic isolation. Hence in many applications, IBDC is used in place of NIBDC. In IBDC, high frequency transformer is used to provide galvanic isolation. Galvanic isolation is necessary in many applications for safety of source in overload condition, for noise reduction, for voltage matching between conditions. This converter works in two stages [39]. In first stage dc is converted to ac and second stage ac is converted into dc and both the stages are con- 
nected through high frequency transformer. The basic circuit of isolated bidirectional dc-dc converter is shown in Fig. 2(d). Since transformer can work only at There are many topologies of isolated converters such as forward-flyback IBDC, dual push-pull IBDC, dual flyback IBDC, Dual-CUK IBDC, Dual half bridge IBDC and Dal active full bridge IBDC [40]-[46]. But half bridge and full bridge are widely used because of their high efficiency [47]-[50].

\subsubsection{Dual Half Bridge (DHB)-Isolated Bidirectional Dc to Dc Converter (IBDC)}

Dual Half Bridge (DHB) isolated ZVS bidirectional dc-dc converters[51] achieve high power density, soft switching and easy control hence are used in EV applications. Fig. 2(e) shows the topology. Its efficiency is 92 to $94 \%$.

\subsubsection{Dual Active Full Bridge (DAFB)-Isolated Bidirec- tional de to dc Converter}

Full bridge isolated bidirectional dc-dc converters are more suitable choice in hybrid energy system because of the high-power density and high efficiency [52]. Fig. 2(f) shows the DAFB-IBDC. The power capacity with the switches so the above discussed DAFB-IBDC has higher power capacity than another topology. Its efficiency is $95 \%$. Hence in high power application like hybrid energy system, this converter is most suitable.

\section{Control Technique for Isolated Bidirectional dc to dc converter}

For power flow in isolated bidirectional dc-dc converter, phase shift technique is used such as single-phase shift technique (SPS), extended phase shift (EPS) technique, double technique (DPS) and triple phase shift (TPS) technique. Single phase shift is widely used method in DAFB-IBDC [53]-[57]. SPS technique has advantages: small inertia, high dynamics and ease of soft switching but power flow suffers from the leakage inductance of transformer. EPS [58], DPS [53], [59], TPS [60] are modified form of SPS.

\section{Switching Techniques}

Hard switching is the main cause for the switching [45], [54]. Hence researchers have developed the soft switching techniques so that switching losses can be minimized. But to achieve soft switching, passive component has to be used which makes the system bulky and complex. Table No. 2 shows the comparison of soft and hard switching.

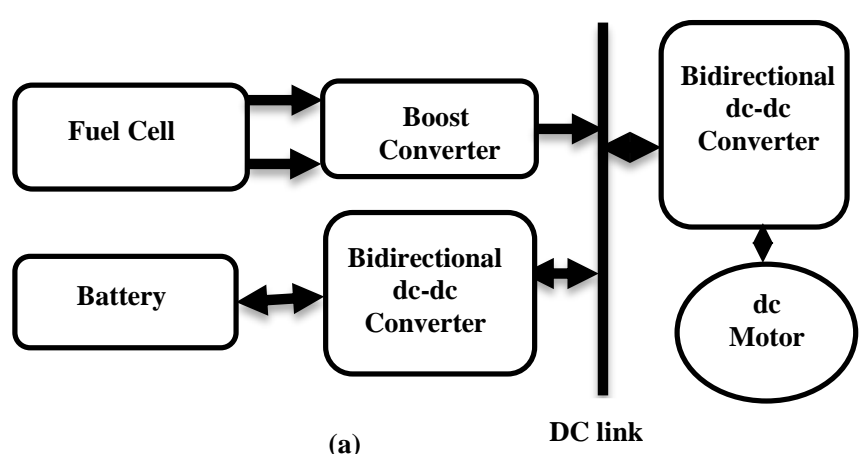

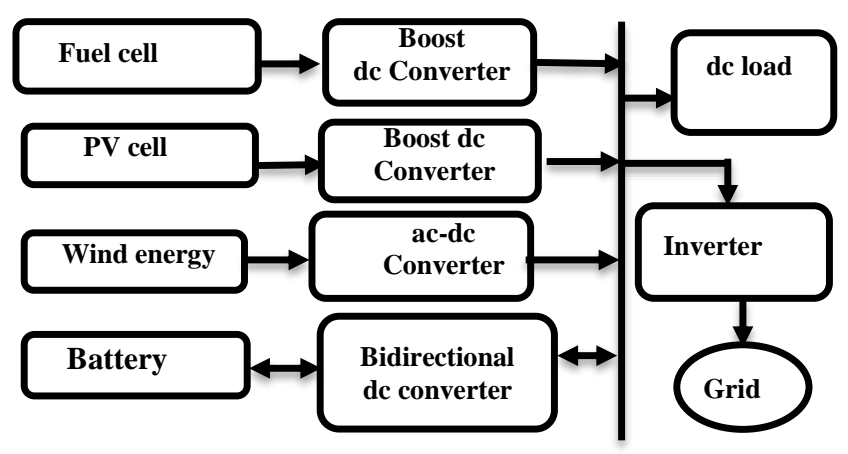

(b)

DC link

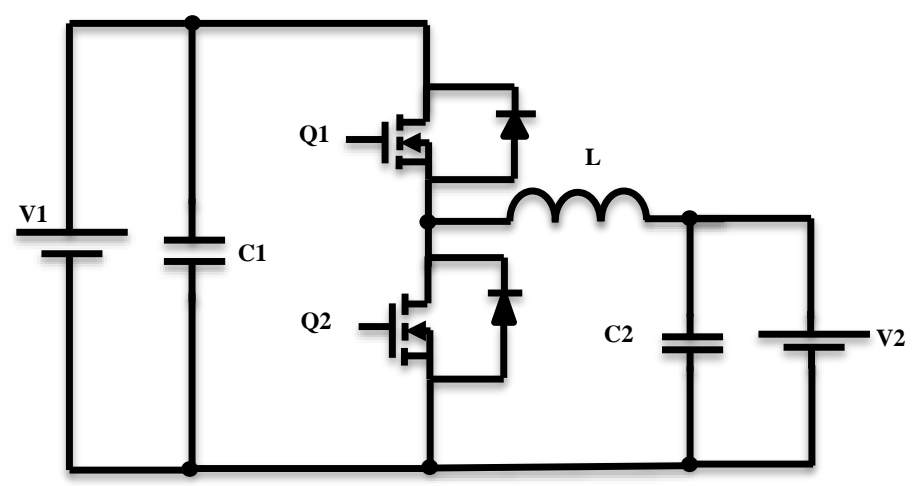

(c)

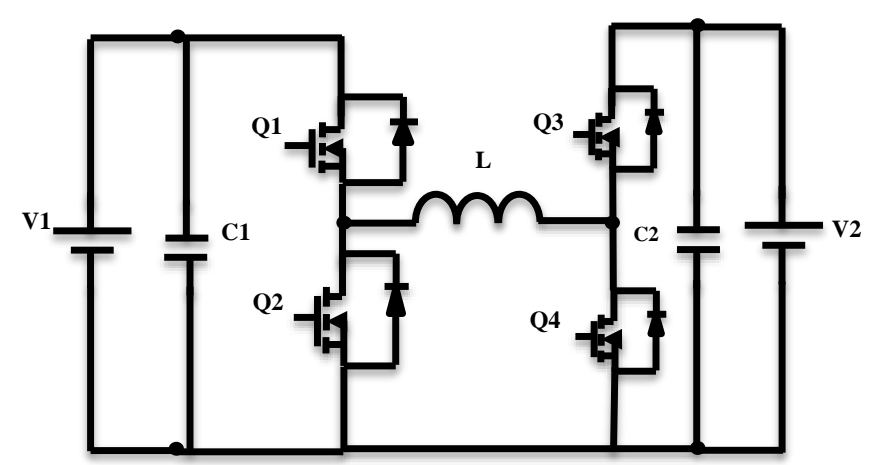

(d)

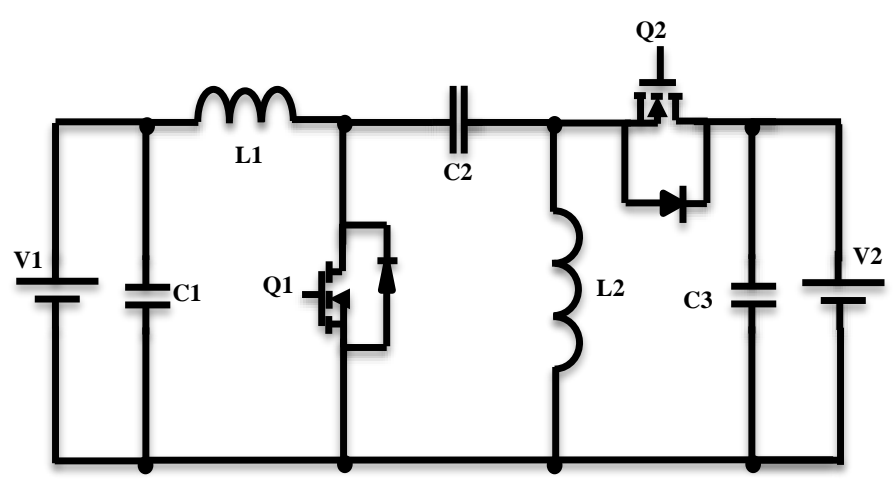

(e)

Fig.1:. (a) Fuel Cell powered Electric Vehicle, (b) Hybrid Energy System with Battery Interface using Bidirectional dc-dc Converter, (c) Bidirectional dc to dc Buck-Boost Converter, (d) Cascaded Bidirectional Buck-boost Converter, (e) Bidirectional CUK Converter 


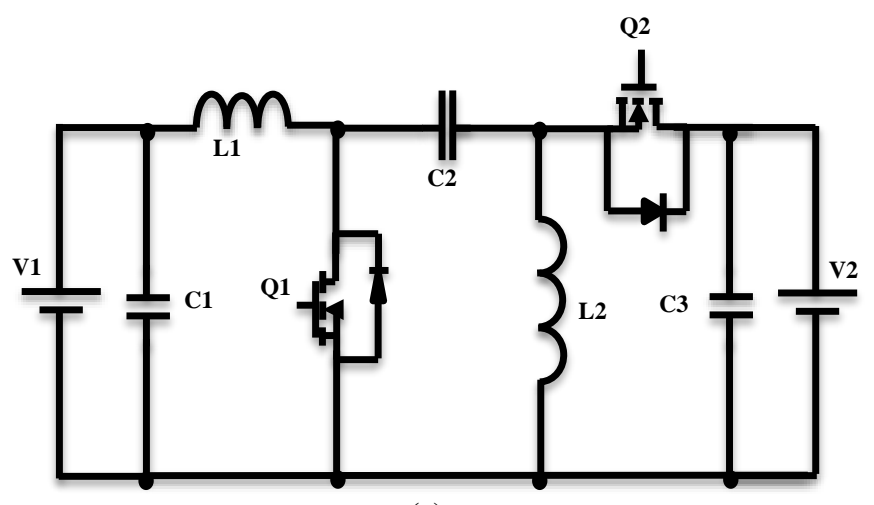

(a)

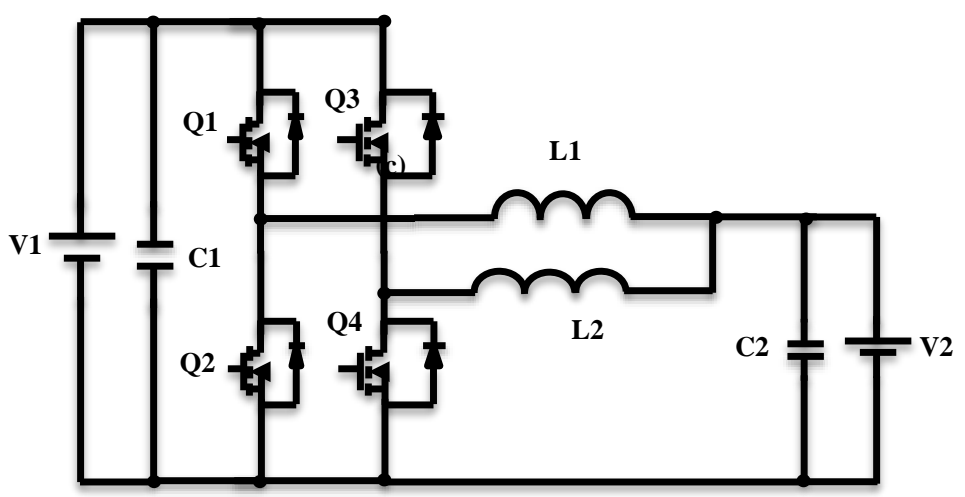

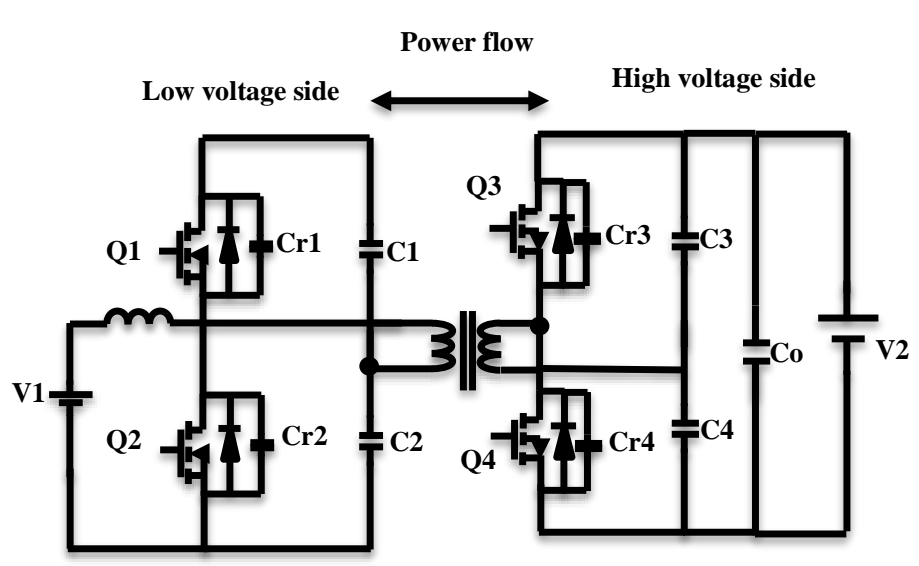

(e)
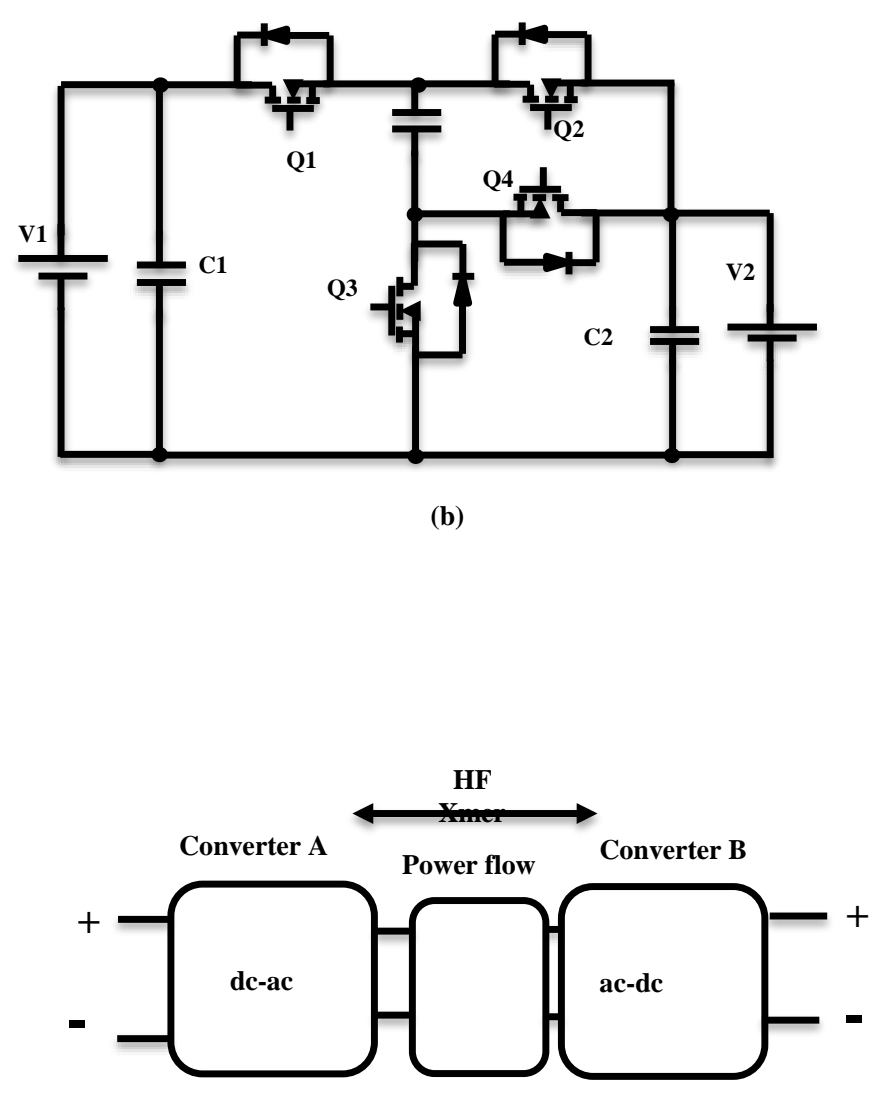

(b)

Low Voltage side Power flow High Voltage side

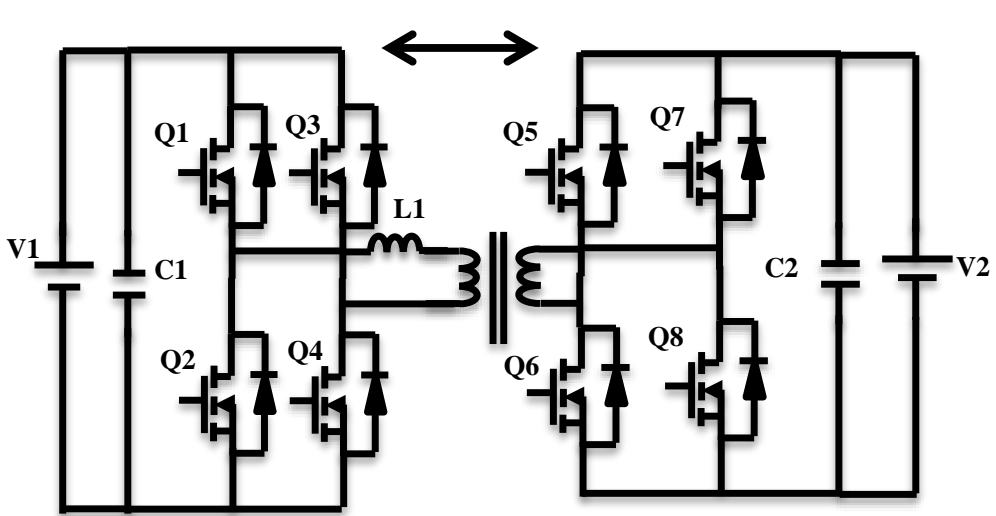

(f)

Fig.2.: (a) Bidirectional SEPIC-ZETA dc-dc Converter, (b) Switched Capacitor Bidirectional dc to dc Converter, (c) 2-phase interleaved half bridge Bidirectional dc-dc converter, (d) Basic Structure of Bidirectional dc-dc Converter, (e) Dual Half Bridge (DHB) Isolated Bidirectional dc-dc (IBDC), (f) DAFB-IBDC

Table 1: Comparison between Soft and Hard Switching

\begin{tabular}{|l|l|}
\hline Hard switching & Soft switching (ZVS and ZCS) \\
\hline Large switching losses & Near zero switching losses \\
\hline High EMI due to high di/dt and dv/dt & Low EMI loss \\
\hline Limited range of switching frequency & High range of switching frequency \\
\hline Low power density & High Power Density \\
\hline Low efficiency & High Efficiency \\
\hline Easy control & Complex Control \\
\hline Low cost & High cost due to more number of switches \\
\hline
\end{tabular}




\section{Conclusion}

From the above discussion it can be concluded that the isolated bidirectional dc-dc converters are large in size and heavier in weight due to presence transformer so theses converters seem to unfit for electric vehicles and non-isolated interleaved bidirectional dc-dc converter are more suitable in electric vehicles. But in high power palpation where galvanic isolation is necessary, IBDC are more suitable for hybrid energy system. Soft switching scheme should be used in place of hard switching because it reduces the switching the losses. In IBDC controlling scheme is used according to complexity of the circuit and application.

\section{Acknowledge}

The authors acknowledge Dr. lini Mathew, NITTTR Chandigarh Dr. Paulson Samuel, MNNIT Allahabad, Bandi Mallikarjna Reddy MNNIT Allahabad for their direction and support. The authors also acknowledge Professor Dinesh Chandra for his support.

\section{References}

[1] F. Caricchi, F. Crescimbini, F. G. Capponi, and L. Solero, "Study of bi-directional buck-boost converter topologies for application in electrical vehicle motor drives," APEC '98 Thirteen. Annu. Appl. Power Electron. Conf. Expo., vol. 1, pp. 287-293, (1998).

[2] [2] converter topology for low power application," PESC97. Rec. 28th Annu. IEEE Power Electron. Spec. Conf. Former. Power Cond Spec. Conf. 1970-71. Power Process. Electron. Spec. Conf. 1972 vol. 1, pp. 804-810, (1997).

[3] J.-S. Lai and D. J. Nelson, "Energy Management Power Converters in Hybrid Electric and Fuel Cell Vehicles," Proc. IEEE, vol. 95, no. 4, pp. 766-777, (2007).

[4] A. Emadi, S. S. Williamson, and A. Khaligh, "Power electronics intensive solutions for advanced electric, hybrid electric, and fuel cell vehicular power systems," IEEE Transactions on Power Electronics, vol. 21, no. 3. pp. 567-577, ( 2006).

[5] H. Plesko, J. Biela, J. Luomi, and J. W. Kolar, "Novel concepts for integrating the electric drive and auxiliary DC-DC converter for hybrid vehicles," IEEE Trans. Power Electron., vol. 23, no. 6, pp. 3025-3034, (2008).

[6] B. M. Reddy and P. Samuel, "Technology Advancements and Trends in Development of Proton Exchange Membrane Fuel Cell Hybrid Electric Vehicles in India : A Review," vol. 7, pp. 361-384, (2017).

[7] M. Y. Chong, A. A. Rahman, N. A. Aziz, A. Khamis, and M. F. M. Basar, "Performance comparison of bidirectional converter designs for renewable power generation," in PEOCO 2010 - 4th International Power Engineering and Optimization Conference, Program and Abstracts, pp. 101-106, (2010).

[8] M. A. Abdullah, A. H. M. Yatim, C. W. Tan, and A. S. Samosir, "Control of a bidirectional converter to interface ultracapacitor with renewable energy sources," in Proceedings of the IEEE International Conference on Industrial Technology, pp. 673-678, (2013).

[9] S. Adhikari, Z. Lei, W. Peng, and Y. Tang, "A Battery / Supercapacitor Hybrid Energy Storage System for DC Microgrids," ECCE Asia, pp. 8-14, (2016).

[10] U. Supatti and S. Sungtum, "Bidirectional hybrid batteries/ultracapacitors energy storage system for vehicular applications," IEEE Ind. Appl. Soc. - 51st Annu. Meet. IAS 2015, Conf. Rec., pp. 6-11, (2015).

[11] H. Zhou, T. Duong, S. T. Sing, and A. M. Khambadkone, "Interleaved bi-directional Dual Active Bridge DC-DC converter for interfacing ultracapacitor in micro-grid application," in IEEE International Symposium on Industrial Electronics, pp. 2229-2234, (2010).

[12] H. Bai and C. Mi, "Eliminate reactive power and increase system efficiency of isolated bidirectional dual-active-bridge dc-dc converters using novel dual-phase-shift control," IEEE Trans. Power Electron., vol. 23, no. 6, pp. 2905-2914, (2008).

[13] [13]J. Xie, X. Zhang, C. Zhang, and C. Wang, "Research on BiDirectional DC-DC Converter For a Stand-Alone Photovoltaic Hy- brid Energy Storage System,” 2010 Asia-Pacific Power Energy Eng. Conf., pp. 1-4, 2010.

[14] J. Li-jun and Y. Guang-yao, "Study of Bi-directional DC-DC Converter of Micro-grid Hybrid Energy Storage System," pp. 11661169, (2015)

[15] M. A. Hernández, F. Lozada, J. L. Azcue, J. A. Torrico, A. J. Sguarezi, and S. Member, "Battery Energy Storage System Applied to Wind Power System Based on Z-Source Inverter Connected to Grid," vol. 14, no. 9, pp. 4035-4042, (2016).

[16] A. Aroliya, "Analysis of Energy Storage System for Wind Power Generation with application of Bidirectional Converter," Second Int Conf. Comput. Intell. Commun. Technol., pp. 419-423, 2016.

[17] S. Tamalouzt, N. Benyahia, T. Rekioua, D. Rekioua, and R. Abdessemed, "Wind turbine-DFIG/photovoltaic/fuel cell hybrid power sources system associated with hydrogen storage energy for microgrid applications," in Proceedings of 2015 IEEE International Renewable and Sustainable Energy Conference, IRSEC 2015, (2016).

[18] J. Barzola, D. L. Simonetti, and J. F. Fardin, "Energy storage systems for power oscillation damping in distributed generation based on wind turbines with PMSG," 2015 Chil. Conf. Electr. Electron. Eng. Inf. Commun. Technol., pp. 655-660, (2015).

[19] H. Karshenas and H. Daneshpajooh, "Bidirectional DC-DC Converters for Energy Storage Systems," Energy Storage Emerg. ERA Smart Grids, pp. 162-178, (2011).

[20] B. M. Reddy and P. Samuel, "A comparative analysis of nonisolated bi-directional dc-dc converters," IEEE 1st International Conference on Power Electronics, Intelligent Control and Energy Systems (ICPEICES), Delhi, India, 2016, pp. 1-6, (2016).

[21] A. k. Gupta, B. M. Reddy, D. Kumar, P. Samuel, "BBBC based Optimization of PI Controller Parameters for Buck Converter," iPACT 2017, Vellore Institute of technology, Vellore, Tamilnadu, India, (2017).

[22] T. Kang, C. Kim, Y. Suh, H. Park, B. Kang, and D. Kim, "A design and control of bi-directional non-isolated DC-DC converter for rapid electric vehicle charging system," in Conference Proceedings IEEE Applied Power Electronics Conference and Exposition APEC, pp. 14-21, (2012).

[23] D. R. Northcott, S. Filizadeh, and A. R. Chevrefils, "Design of a bidirectional buck-boost dc/dc converter for a series hybrid electric vehicle using PSCAD/EMTDC," in 5th IEEE Vehicle Power and Propulsion Conference, VPPC '09, 2009, pp. 1561-1566, (2009).

[24] R. M. Schupbach and J. C. Balda, "Comparing DC-DC converters for power management in hybrid electric vehicles," IEEE Int. Electr. Mach. Drives Conf. 2003. IEMDC'03., vol. 3, no. C, pp. 13691374, (2003).

[25] M. R. Mohammadi and H. Farzanehfard, "A new bidirectional ZVS-PWM Cuk converter with active clamp,” 2011 19th Iran. Conf. Electr. Eng., pp. 1-1, (2011).

[26] K. Tytelmaier, O. Husev, O. Veligorskyi, and R. Yershov, "A review of non-isolated bidirectional dc-dc converters for energy storage systems," 2016 II Int. Young Sci. Forum Appl. Phys. Eng., pp. 22-28, (2016).

[27] E. Adib and H. Farzanehfard, "Soft switching bidirectional DC-DC converter for ultracapacitor-batteries interface," Energy Convers. Manag., vol. 50, no. 12, pp. 2879-2884, 2009.

[28] C. Dimna Denny and M. Shahin, "Analysis of bidirectional SEPIC/Zeta converter with coupled inductor," Proc. IEEE Int. Conf. Technol. Adv. Power Energy, TAP Energy 2015, pp. 103-108, (2015).

[29] I. D. Kim, Y. H. Lee, B. H. Min, E. C. Nho, and J. W. Ann, "Design of bidirectional PWM Sepic/Zeta DC-DC converter," 7th Internatonal Conf. Power Electron. ICPE'07, pp. 614-619, (2008).

[30] Y.-S. Lee and Y.-Y. Chiu, "Zero-current-switching switchedcapacitor bidirectional DC-DC converter," IEE Proc. - Electr. Power Appl., vol. 152, no. 6, pp. 1525-1530, (2005).

[31] A. Ioinovici, "Development of a Generalized S witched-Capacitor DCDC Converter with Bi-directional Power Flow," pp. 499-502, (2000).

[32] H. S. H. Chung, A. Ioinovici, and W. L. Cheung, "Generalized structure of bi-directional switched-capacitor DC/DC converters," IEEE Trans. Circuits Syst. I Fundam. Theory Appl., vol. 50, no. 6, pp. 743-754, (2003).

[33] S. Sakulchotruangdet and S. Khwan-On, "Three-phase Interleaved Boost Converter with Fault Tolerant Control Strategy for Renewable Energy System Applications," Procedia Comput. Sci., vol. 86, no. March, pp. 353-356, (2016). 
[34] X. Huang, F. C. Lee, Q. Li, and W. Du, "High-Frequency HighEfficiency GaN-Based Interleaved CRM Bidirectional Buck/Boost Converter with Inverse Coupled Inductor," IEEE Trans. Power Electron., vol. 31, no. 6, pp. 4343-4352, (2016).

[35] Y. Yang, J. Ma, C. N. M. Ho, and Y. Zou, "A New CoupledInductor Structure for Interleaving Bidirectional DC-DC Converters," IEEE J. Emerg. Sel. Top. Power Electron., vol. 3, no. 3, pp. 841-849, (2015).

[36] W. Yu, H. Qian, and J. S. Lai, "Design of high-efficiency bidirectional DCDC converter and high-precision efficiency measurement," IEEE Trans. Power Electron., vol. 25, no. 3, pp. 650-658, (2010).

[37] A. Thiyagarajan, S. G. Praveen Kumar, and A. Nandini, "Analysis and Comparison of Conventional and Interleaved DC/DC Boost Converter," Second Int. Conf. Curr. Trends Eng. Technol. - ICCTET 2014, pp. 198-205, (2014).

[38] S. Waffler, J. Biela, and J. W. Kolar, "Output ripple reduction of an automotive multi-phase Bi-directional DC-DC converter," in 2009 IEEE Energy Conversion Congress and Exposition, ECCE 2009, pp. 2184-2190, (2009).

[39] B. M. Reddy, P. Samuel, "Analysis of Isolated Bi-Directional dc-dc Converters for Performance Enhancement of PV System and Energy Storage System," PIICON-2016, Government engineering college, Bikaner, India, (2016).

[40] H. S. H. Chung, W. L. Cheung, and K. S. Tang, "A ZCS bidirectional flyback dc/dc converter," IEEE Trans. Power Electron., vol. 19, no. 6, pp. 1426-1434, (2004).

[41] M. Kashif, "Bidirectional flyback DC-DC converter for hybrid electric vehicle: Utility, working and PSPICE computer model," Asia Pacific Conf. Postgrad. Res. Microelectron. Electron., no. December, pp. 61-66, (2012).

[42] D. Murthy-Bellur and M. K. Kazimierczuk, "Isolated two-transistor zeta converter with reduced transistor voltage stress," IEEE Trans. Circuits Syst. II Express Briefs, vol. 58, no. 1, pp. 41-45, (2011).

[43] F. Zhang and Y. Yan, "Novel forward-flyback hybrid bidirectional DC-DC converter," IEEE Trans. Ind. Electron., vol. 56, no. 5, pp. 1578-1584, (2009).

[44] H. Li, F. Z. Peng, and J. S. Lawler, "A natural ZVS medium-power bidirectional DC-DC converter with minimum number of devices," IEEE Trans. Ind. Appl., vol. 39, no. 2, pp. 525-535, (2003).

[45] Z. Zhang, Z. Ouyang, O. C. Thomsen, and M. A. E. Andersen, "Analysis and design of a bidirectional isolated DC-DC converter for fuel cells and supercapacitors hybrid system," IEEE Trans. Power Electron., vol. 27, no. 2, pp. 848-859, (2012).

[46] J.-Y. Lee, Y.-S. Jeong, and B.-M. Han, "A Two-Stage Isolated/Bidirectional DC/DC Converter With Current Ripple Reduction Technique," IEEE Transactions on Industrial Electronics, vol. 59, no. 1. pp. 644-646, (2012)

[47] R. Pittini, Z. Zhang, M. a E. Andersen, and K. Lyngby, "Analysis of DC / DC Converter Efficiency for Energy Storage System Based on Bidirectional Fuel Cells," pp. 2011-2014, (2014).

[48] B. Zhao, Q. Yu, Z. Leng, and X. Chen, "Switched Z-source isolated bidirectional dc-dc converter and its phase-shifting shoot-through bivariate coordinated control strategy," IEEE Trans. Ind. Electron., vol. 59, no. 12, pp. 4657-4670, (2012).

[49] T. Hirose and H. Matsuo, "A consideration of bidirectional superposed dual active bridge dc-dc converter," in 2nd International Symposium on Power Electronics for Distributed Generation Systems, PEDG 2010, pp. 39-46, (2010).

[50] L. Zhu, "A novel soft-commutating isolated boost full-bridge ZVSPWM DC-DC converter for bi-directional high power applications," in PESC Record - IEEE Annual Power Electronics Specialists Conference, vol. 3, pp. 2141-2146, (2004)

[51] H. Li, D. Liu, F. Z. Peng, and G. J. Su, "A small signal analysis of a dual half bridge isolated ZVS Bi-directional dc-dc converter for electrical vehicle applications," in PESC Record - IEEE,, Annual Power Electronics Specialists Conference, vol. 2005, pp. $2777-$ 2782, (2005).

[52] L. Solero, F. Caricchi, F. Crescimbini, O. Honorati, and F. Mezzetti, "Performance of a $10 \mathrm{~kW}$ power electronic interface for combined wind/PV isolated generating systems," PESC Rec. 27th Annu. IEEE Power Electron. Spec. Conf., vol. 2, pp. 1027-1032, (1996).

[53] M. H. Kheraluwala, R. W. Gascoigne, D. M. Divan, and E. D. Baumann, "Performance Characterization of a High-Power Dua Active Bridge dc-to-dc Converter," IEEE Trans. Ind. Appl., vol. 28 no. 6, pp. 1294-1301, (1992).
[54] R. W. A. A. De Doncker, D. M. Divan, and M. H. Kheraluwala, "A Three-Phase Soft-Switched High-Power-Density DC/DC Converter for High-Power Applications," IEEE Trans. Ind. Appl., vol. 27, no. 1, pp. 63-73, (1991)

[55] M. H. Kheraluwala and R. W. De Doncker, "Single phase unity power factor control for dual active bridgelnconverter," in Conf Rec. 28th IEEE Industry Applications Soc. (IAS) Annu. Meeting, (1993).

[56] S. Inoue and H. Akagi, "A bidirectional isolated dc-dc converter as a core circuit of the next-generation medium-voltage power conversion system," IEEE Trans. Power Electron., vol. 22, no. 2, pp. 535542, (2007).

[57] S. Inoue and H. Akagi, "A bidirectional DC-DC converter for an energy storage system with galvanic isolation,” IEEE Trans. Power Electron., vol. 22, no. 6, pp. 2299-2306, (2007).

[58] G. G. Oggier, R. Leidhold, G. O. García, A. R. Oliva, J. C. Balda, and $\mathrm{F}$. Barlow, "Extending the ZVS operating range of dual active bridge high-power DC-DC converters," in PESC Record - IEEE Annual Power Electronics Specialists Conference, (2006).

[59] H. Bai, Z. Nie, and C. C. Mi, "Experimental comparison of traditional phase-shift, dual-phase-shift, and model-based control of isolated bidirectional dc-dc converters," IEEE Trans. Power Electron. vol. 25 , no. 6 , pp. 1444-1449, (2010).

[60] G. G. Oggier, G. O. GarcÍa, A. R. Oliva, G. O. Garcia, and A. R. Oliva, "Switching Control Strategy to Minimize Dual Active Bridge Converter Losses," IEEE Trans. Power Electron., vol. 24 no. 7, pp. 1826-1838, (2009). 